\title{
ОБЛІКОВО-АНАЛІТИЧНЕ ЗАБЕЗПЕЧЕННЯ ДІАГНОСТИКИ ФУНКЦІОНУВАННЯ ПІДПРИЕМСТВА ТА УДОСКОНАЛЕННЯ СИСТЕМИ ЕКОНОМІЧНОЇ БЕЗПЕКИ НА ОСНОВІ ПОКРАЩЕННЯ ФІНАНСОВОГО СТАНУ
}

\section{ACCOUNTING AND ANALYTICAL PROVISION OF DIAGNOSTICS OF THE FUNCTIONING OF THE ENTERPRISE AND IMPROVEMENT OF THE SYSTEM OF ECONOMIC SAFETY ON THE BASIS OF BASIS}

\author{
Губарик Ольга Миколаївна \\ кандидат економічних наук, доцент, \\ Дніпровський державний аграрно-економічний університет \\ ORCID: https://orcid.org/0000-0002-3296-2074 \\ Юрченко Аліна Анатоліївна \\ здобувач другого рівня вищої освіти, \\ Дніпровський державний аграрно-економічний університет \\ ORCID: https://orcid.org/0000-0002-2138-8951 \\ Hubaryk Olha, Yurchenko Alina \\ Dnipro State University of Agriculture and Economics
}

Всі підприємства здійснюючи свою господарську діяльність мають на меті підвищувати ефективність функціонування діяльності, забезпечити високий рівень конкурентоздатності продукції, товарів, робіт та послуг, забезпечити впровадження новітніх досягнень в галузі науки з метою удосконалення виробничого процесу. Підгрунтям для досягнення поставлених цілей є забезпечення економічної безпеки підприємства. Для цього необхідно постійно здійснювати перевірку діяльності з метою виявлення слабких місць та зосередження уваги на їх усуненні або мінімізації впливу на результати діяльності. Дана стаття присвячена актуальним питанням обліково-аналітичного забезпечення діагностики функціонування підприємства; відображено вимоги які ставлять аналітики до інфрормації, для забезпечення правдивості отриманих результатів; розкрито принципи механізму функціонування системи економічної безпеки; наведено визначення поняття «діагностики», здійснена порівняльна характеристика поглибленої та експрес-діагностики; наведено перелік заходів для збереження поточного фрінансового стану та запропоновано шляхи для його покращення.

Ключові слова: обліково-аналітичне забезпечення, ризики, фрінансовий стан, діагностика.

Все предприятия, осуществляя свою хозяйственную деятельность, имеют цель повышать эффрективность фрункционирования деятельности, гарантировать высокий уровень конкурентоспособности продукции, товаров, работ и услуг, обеспечить внедрение новейших достижений в области науки с целью усовершенствования производственного процесса. Основанием для достижения поставленных целей является создание условий экономической безопасности предприятия. Для этого необходимо постоянно осуществлять проверку деятельности с целью выявления слабых мест и сосредоточить внимание на их устранении или минимизации влияния на результаты деятельности. Данная статья посвящена актуальным вопросам учетно-аналитического обеспечения диагностики функционирования предприятия; отражены требования, предъявляемые аналитиками к инорормации, для обеспечения правдивости полученных результатов; раскрыты принципы механизма фрункционирования системы экономической безопасности; приведено определение понятия «диагностики», осуществлена сравнительная характеристика углубленной и экспресс- диагностики; приведен перечень мер по сохранению текущего фринансового положения и предложены пути его улучшения.

Ключевые слова: учетно-аналитическое обеспечение, риски, фринансовое состояние, диагностика. 
In modern business conditions before the heads of the enterprise and their authorized persons the question of ensuring economic security of activity is acute, but the ways to ensure it involve certain obstacles. Modern transformations were filled with new economic content, thus causing certain changes in the order of economic conditions. All enterprises carrying out their economic activities aim to increase the efficiency of operations, to ensure a high level of competitiveness of products, goods, works and services, to ensure the introduction of the latest advances in science in order to improve the production process. The basis for achieving the goals is to ensure the economic security of the enterprise, for this it is necessary to constantly check the activities in order to identify weaknesses and focus on their elimination or minimize the impact on performance. All this is achieved by periodically diagnosing the financial condition of the entity. To ensure a high level of business security, entrepreneurs should pay close attention to the order of information support, because the possession of the necessary amount of information is the key to rational implementation in future analysis, identifying shortcomings and drawing conclusions and developing an action plan to prevent negative consequences. The basis of the information base is accounting data, which have their generalized reflection in the financial statements of the enterprise. But for in-depth analysis, employees also use other sources to cover a larger array of data, thus ensuring the reliability and veracity of the results, which will be the basis for developing plans to maintain the status quo and ensure future development of the enterprise. This article is devoted to topical issues of accounting and analytical support for diagnostics of the enterprise; reflects the requirements of analysts to information to ensure the veracity of the results; the principles of the mechanism of functioning of the economic security system are revealed; the definition of the concept of «diagnostics» is given, the comparative characteristic of express diagnostics and in-depth is carried out; a list of measures to maintain the current financial situation and suggested ways to improve it.

Keywords: accounting and analytical support, risks, financial condition, diagnostics.

Постановка проблеми. В умовах сучасної України актуальність економічної безпеки підтверджується появою нових і загостренням існуючих зовнішніх і внутрішніх загроз. Становлення ринкової економіки та зростання пріоритетності фрінансових ресурсів на підприємстві, об'єктивно сприяли розвитку такого важливого напрямку роботи аналітика 3 економічної безпеки підприємства як діагностика його діяльності за допомогою фрінансового аналізу. Він $€$ складовою загальноекономічного аналізу господарської діяльності. Лише за умови належного його проведення підприємство має можливість зберегти міцні ринкові позиції в умовах жорсткої конкуренції. Для досягнення певних результатів необхідно зосередити увагу на обліково-аналітичному забезпеченні, в основу якої покладено систему збору, обробки та оцінки інформації, яка базується на різного роду даних. Спираючись на історичний досвід, можна побачити, що проблемі забезпечення економічної безпеки суспільства, а також суб'єктів господарювання повинні приділяти особливу увагу. Тому важливим $€$ питання обліково-аналітичного забезпечення економічної безпеки суб'єктів господарювання.

Аналіз останніх досліджень та публікацій. Багато науковців приділяє питанню обліково-аналітичного забезпечення велику увагу. Донайвідомішихможнавіднести: Бенько М.М., Акімова Н. С., Крамська М. С., Бланк І. А., Брадул О. М., Гнилицька Л. В. Метою їх наукових робіт є дослідження обліково-аналітичного забезпечення процесу фрункціонування системи економічної безпеки суб'єктів госпо- дарювання, як об'єкт наукових досліджень та зосередження уваги на проблемах обліковоаналітичного забезпечення в системі економічної безпеки підприємства.

Окремо можна виділити вчених та науковців чиї праці присвячені дослідженню питань проведення діагностики та аналізу діяльності підприємства. До їх числа можна віднести Градову А. В., Загорну Т. О., Лук'янова В. В., Савицьку Г. В., Копчак Ю. С. та інших.

Формулювання цілей статті (постановка завдання). Метою статті $€$ дослідження $€$ детальна характеристика механізму функціонування системи економічної безпеки. Порядок формування інфрормації та розкриття основних вимог, які ставляться аналітиками в ході здійснення свої роботи. Характеристика основних методів діагностики діяльності, порядок формування мети, завдань та підходів, що будуть застосовуватися при діагностиці діяльності суб'єкта господарювання, порядок отримання результатів, їх аналіз та заходи спрямовані на створення дієвих заходів для покращення фрінансового стану об'єкта в цілому.

Виклад основного матеріалу дослідження. Економічна безпека підприємства $€$ складним і багатогранним поняттям. Складність і багатогранність цього поняття обумовлена тим, що успішна діяльність і динамічний розвиток підприємства, отже їх економічна безпека, в тій чи іншій мірі залежить практично від усіх фрункціональних складових їх діяльності. Іншими словами економічна безпека залежить від усіх структурних елементів підприємств, виду діяльності, посадових осіб, 
управлінських рішень, впровадженої техніки і технології, тощо. Тобто все, що знаходиться в підприємстві і все, чим займається підприємство впливає на стан їх економічної безпеки.

У зв'язку з цим останнім часом поняття «економічної безпеки» займає особливе місце серед понять, і є відносно новим. Це обумовлено тим, що основою економічного благополуччя будь-якого господарюючого суб'єкта $є$ не тільки максимізація прибутку, але й економічна безпека, а необхідність постійного забезпечення економічної безпеки зумовлюється об'єктивно наявним для кожного підприємством завданням забезпечення стабільності фрункціонування і досягнення головних цілей своєї діяльності.

Економічна безпека підприємства в теперішній час $€$ вагомою частиною його фрінансово-господарського стану. Внутрішнє і зовнішне середовище фрункціонування суб'єктів господарської діяльності в Україні має безліч видів небезпек і загроз, які створюються відповідно до сучасних характерних особливостей вітчизняної економічної системи. Загрози економічній безпеці підприємства зазвичай пов'язані з різнобічними ризиками діяльності. Поняття ризику пов'язується 3 усвідомленням небезпеки, загрози, ненадійності, невизначеності, непевності, випадковості, збитку. У широкому сенсі під ризиком прийнято розуміти ймовірність (загрозу) втрати підприємством частини своїх ресурсів, недоодержання доходів чи появи додаткових витрат у результаті здійснення певної виробничої і фрінансової діяльності. Також поняття ризику пов'язують із:

1) потенційною, чисельно вимірною можливістю втрати. Поняттям ризику характеризується невизначеність, пов'язана 3 можливістю виникнення в ході реалізації проекту несприятливих ситуацій і наслідків;

2) імовірністю виникнення втрат, збитків, недонадходжень запланованих доходів, прибутку;

3) невизначеністю фрінансових результатів у майбутньому;

4) ступенем невизначеності одержання майбутніх чистих доходів;

5) вартісним вираженням ймовірної події, що веде до втрат;

6) шансом несприятливого результату, небезпеки, загрози втрат;

7) імовірністю втрати цінностей (фрінансових, матеріальних, товарних ресурсів) у результаті діяльності, якщо обставини й умови проведення діяльності будуть змінюватися в напрямку, відмінному від передбаченого планами і розрахунками.

Загрози діяльності підприємства бувають зовнішніми і внутрішніми.

До зовнішніх загроз належать: протиправна діяльність кримінальних структур, конкурентів, фрірм і фрізичних осіб, що займаються промисловим шпигунством або шахрайством, неспроможність ділових партнерів, протиправна діяльність раніше звільнених робітників, тощо.

До внутрішніх загроз належать дії пасивності (у тому числі умисні та ненавмисні) співробітників підприємства, що суперечать інтересам його комерційної діяльності.

Для того, щоб протистояти загрозам які постійно, в тій чи іншій мірі, діють на фрінансово-господарську діяльність підприємства необхідно здійснювати постійний контроль, але для його ефективного проведення необхідно мати інфоормацію, яка б відповідала певного роду характеристикам.

Центральне місце у складі інфрормаційного забезпечення економічної безпеки займає обліково-аналітична інфрормація. Обліковоаналітична інфрормація містить у собі економічні відомості про осіб, сракти, процеси, явища, які відбуваються на підприємстві.

Для ефрективного управління господарськими процесами отримана у результаті діяльності інформація повинна мати певний рівень захисту для того, щоб її використання забезпечувало економічну безпеку суб'єкта господарювання. Дана інформація базується на даних бухгалтерського обліку, які фріксують усі господарські операції на підприємстві, а також дані аналізу господарської діяльності. Саме бухгалтерія знаходиться на стику інсрормаційних потоків різних підрозділів підприємства і практично тільки вона може фрормувати інорормацію про реальний стан справ суб'єкта господарювання [3].

У теперішніх умовах господарювання важливим для розвитку діяльності $€$ зростання ролі звітних даних, як джерела правдивої, достовірної і об'єктивної інформації про фрінансово-господарську діяльність, особливо даних, що відображені у фрінансовій звітності, що фрормується в системі фрінансового обліку, як складової частини системи обліково-аналітичної безпеки підприємства. Усі нам відомі регістри синтетичного і аналітичного обліку та фрінансової звітності містять цілий ряд показників, які певним чином між собою взаємопов'язані і тим самим надають інформацію про виробничогосподарську діяльність. 
Але окрім даних отриманих за допомогою бухгалтерського обліку, в аналізу господарської діяльності також широко застосовується планова інформація і статистична (дані статистичного обліку) та інші види управлінського спрямування, до їх складу можна віднести: оперативну, фрінансову, статистичну, технічну, технологічну, соціальну та інші види інфрормації, що необхідні для здійснення детального аналізу. Найбільшу питому вагу для здійснення діагностики підприємства $€$ дані бухгалтерського обліку, а саме фрінансова звітність. Лише за допомогою поєднання всі видів інфооммації досягається можливість зробити висновки фрінансово-господарської діяльності підприємства в цілому.

Механізмом фоункціонування системи обліково-аналітичного-забезпечення економічної безпеки підприємства є сукупність законодавчих актів, правових норм, спонукальних мотивів і стимулів, методів і засобів, за допомогою яких здійснюється ціле направлення діяльність в області обліково-аналітичного-забезпечення економічної безпеки підприємства.

Механізм фрункціонування системи визначається наступними фракторами:

- організаційно-правовою фрормою функціонування підприємства;

- галузевими особливостями і специфрікою підприємства;

- об'ємом і ступенем диверсифрікації (розширення напрямків діяльності) господарської діяльності підприємства;

- завданням, які ставляться перед службою економічної безпеки;

- підготовленістю персоналу;

- стратегією розвитку підприємства тощо.

Механізм фрункціонування системи обліковоаналітичного-забезпечення економічної безпеки забезпечує: збір інфрормації; способи узагальнення інорормації; оцінку достовірності інформації та її аналіз; технологічне подання інфрормації користувачам; достовірне визначення рівня і стану економічної безпеки підприємства.

Механізм ффункціонування системи обліково-аналітичного-забезпечення економічної безпеки містить наступні складові: правову; методичну; технологічну; організаційну; інфрормаційну.

1. Правова складова забезпечує формування організаційно-правового механізму фрункціонування системи обліково-аналітичного забезпечення економічної безпеки підприємства і включає: законодавчі акти України; укази Президента України; постанови Верховної Ради України; постанови та розпо- рядження Кабінету Міністрів України; накази та розпорядження Міністерств, відомств та державних адміністрацій України; рішення органів місцевого самоврядування України; накази та розпорядження підприємств, установ та інших організацій України (локальні нормативно-правові акти).

2. Методична складова передбачає застосування різноманітних методів - способів виконання окремих робіт чи реалізація окремих процедур для досягнення поставленої мети.

3. Технологічна складова - наявність сучасних прогресивних технологій збору, накопичення, обробки, систематизації, подання інформації користувачам.

4. Організаційна складова - організаційна структура господарського обліку, аналізу і контролю господарської діяльності підприємства, служби економічної безпеки підприємства.

5. Інфрормаційна складова забезпечує збір, обробку, накопичення, оцінку інфрормації про факти та показники господарського життя, фрактори зовнішнього і внутрішнього середовища з метою оцінки рівня і стану економічної безпеки підприємства, його потенційних партерів і конкурентів, а також фрормування стратегії і тактики протидії загрозам діяльності підприємства і його майбутньому розвитку.

Обліково-аналітичне забезпечення $є$ складовою інформаційного забезпечення підприємства і представляє собою цілісну інформаційну систему, де головним $€$ забезпечення якісною та своєчасною економічною інсрормацією зацікавлених у цьому користувачів.

Відповідно до цього визначення та ролі в процесі гарантування економічної безпеки підприємства, обліково-аналітична інорормація має відповідати таким вимогам [1]:

1. Достовірність - основна якісна характеристика, яка впливає на зниження ризику впливу зовнішніх та внутрішніх загроз на економічну безпеку.

2. Точність (не допускається неоднозначне тлумачення).

3. Своєчасність. Отримана інфрормація $€$ корисною для прийняття управлінського рішення і використана перш ніж вона втратить здатність впливати на рішення.

4. Ретроспективність - характеризує події, фракти, явища, які вже відбулися, на які вже неможливо вплинути, змінити їх хід і наслідки.

5. Адекватність (відповідає певному процесу, реальному становищу об'єкта управління та інші).

6. Цінність (знижує стан невизначеності про об'єкт, суб'єкт). 
7. Стислість (лаконічність) - максимально вичерпна та легкодоступна для сприйняття.

8. Релевантність - майбутня (прогностична) інфрормація, яка може бути змінена під впливом певних управлінських рішень. Саме таку інорормацію надає управлінський (внутрішньогосподарський) облік.

9. Закритість (конфріденційність) - не тільки для зовнішніх, але і для внутрішніх користувачів, які не мають прямого відношення до вирішення тої чи іншої проблеми. Містить дані, що $є$ комерційно. таємницею.

10. Повнота - відображає усі фракти господарської діяльності на основі дотримання принципу раціонального ведення обліку та аналізу - затрати на облік і аналіз менші за вигоди від використання обліково-аналітичної інфрормації, її кількість (інформативність) достатня для прийняття рішення.

11. Конкурентоздатність - обліково-аналітична інорормація виступає додатковим корпоративним ресурсом підприємства, без якого фрункціонування системи забезпечення економічної безпеки неможливе.

12. Багатофрункціональність - звична для розуміння як безпосередніх користувачів так і для зацікавлених осіб, що не мають економічної та бухгалтерської освіти.

Дослідження суб'єктів обліково-аналітичного забезпечення залежно від виду інфрормації (облікова або аналітична) дозволяє визначити відмінності в групах користувачів. Інформація фрінансового обліку використовується зовнішніми і внутрішніми користувачами. Зовнішні користувачі використовують переважно узагальнену інфрормацією, яка надається у вигляді показників фрінансової звітності. Внутрішні користувачі приймають рішення на основі поточної інсрормації фрінансового обліку, а також даних управлінського обліку. Аналітична інформація найчастіше застосовується для аналізу фрінансового стану та фрінансово-господарської діяльності з метою визначення відхилень в поточній діяльності та прийняття рішень у майбутньому. Цінність обліково-аналітичного забезпечення полягає в тому, що обліковоаналітична інфрормація, сорормована з використанням як методів бухгалтерського обліку (спостереження, вимірювання, реєстрація, групування, класифрікація й узагальнення), так й економічного аналізу (порівняння, елімінування, статистичні, балансові та ін.).

3 метою забезпечення максимального ступеня захисту від загроз необхідно організувати певну діяльність, яка буде забезпечувати фрінансову безпеку фрірми. Розгляд загроз дає змогу підготувати основу для сукупного аналізування ефективності заходів, що застосовуються для забезпечення економічної безпеки підприємства.

До одного з основних засобів забезпечення ефективного фонкціонування системи фрінансової безпеки підприємства можна віднести узгоджене застосування методів діагностики ризиків та оцінювання збитків як бази та інструменту контролю, а також орієнтира під час планування та здійснення фрінансово-господарської діяльності підприємства.

Діагностикою можна назвати процес дослідження діяльності суб'єкта господарювання за допомогою певного набору методичних розробок, який дозволяє на ранніх стадіях виявити ризики, які можуть порушити сталий хід економічних процесів на підприємстві. Метою здійснення діагностики є здійснення всеохоплюючого аналізу діяльності суб'єкту господарювання. До основних завдань, які ставляться перед початком проведення $є$ :

- проведення аналізу зовнішнього і внутрішнього середовища;

- вивчення кризового середовища та виокремлення з сукупності ризиків, ті які спричинять найбільшу шкоду діяльності підприємства;

- оцінка ймовірності настання кризових ситуацій;

- здійснення аналізу роботи підприємства та виділення проблемних місць;

- фрормування висновків за результатами аналізу, визначення стану фрункціонування об'єкту управління;

- пошук резервів, як можна використати для поліпшення або відновлення ситуації.

Від мети залежить ступінь деталізації і глибина досліджень по окремих напрямках аналізу: рентабельності та фрінансової стійкості; есрективності використання майна: стан забезпеченості підприємства оборотними активами; оцінка динаміки ліквідності, платоспроможності; аналіз ділової активності: визначення ефективності використання фрінансових ресурсів.

Отримання результатів розрахунків цих показників для вітчизняних підприємств, а також їх детальний розгляд допоможе прийняти необхідні рішення,що дозволять мінімізувати вплив негативних чинників на діяльності підприємства, прийняти раціональні і відповідні управлінські рішення, ссрормувати план дій та реалізовувати заходи, які спрямовані на швидке підвищення платоспроможності, забезпечити задовільний рівень стійкості 
фрінансового стану, прибутковості, розвиток фрінансового потенціалу підприємства.

Діагностику фрінансового стану підприємства можна проводити за такими видами: експрес-діагностика; поглиблена діагностика. Порівняємо дані види на основі певних критеріїв (таблиця 1).

Вказані види діагностики забезпечують комплексний аналіз фрінансового стану підприємства.

Виділяють наступні фрорм проведення діагностики фрінансового стану суб'єкта господарювання:

- оцінювання діяльності підприємств, іншими словами, проведення аналізу показників, що визначають ефективність діяльності, згідно зі стратегічними цілями підприємства;

- здійснення експрес-діагностики фрінансового стану підприємства, тобто проведення аналізу системи взаємопов'язаних показників, які визначають загальний фрінансовий стан діяльності підприємства;
- здійснення контролю фрінансових показників, що визначать наслідки фрінансової діяльності, для нейтралізації негативної динаміки.

Не існує універсальної системи діагностики фрінансового стану, яка б відповідала всім вимогам, які ставляться підприємством, бо кожен суб'єкт самостійно встановлює мету даного аналізу відповідно до існуючих на ньому чинників, які можуть призвести до погіршення фрінансового стану. Також необхідно зазначити, що зміни стосуються і переліку множини оцінювальних показників, які змінюються в залежності від галузевого клімату, їі специфріки, умов фрункціонування та впливу середовища.

Алгоритм дій для підтримки фрінансового стану:

- розробка заходів, що дозволять зменшити вразливості підприємства від зовнішнього середовища;

- розробка планів, що дозволять протистояти наслідкам при виникненні проблемних

Таблиця 1

\section{Порівняльна характеристика видів проведення діагностики фрінансового стану підприємства}

\begin{tabular}{|c|c|c|}
\hline Критерії оцінки & Експрес-діагностика & Поглиблена діагностика \\
\hline Терміни проведення & Швидке проведення & Тривале здійснення перевірки \\
\hline $\begin{array}{c}\text { Дані, що } \\
\text { використовуються } \\
\text { для здійснення } \\
\text { діагностики }\end{array}$ & $\begin{array}{l}\text { Фінансова звітність, дані } \\
\text { бухгалтерського обліку, первинні } \\
\text { документи, зведені відомості, } \\
\text { регістри обліку. }\end{array}$ & $\begin{array}{l}\text { Фінансова звітність, дані } \\
\text { бухгалтерського обліку, } \\
\text { первинні документи, зведені } \\
\text { відомості, регістри обліку, } \\
\text { дані управлінського обліку, } \\
\text { статистична звітність. }\end{array}$ \\
\hline Mema & $\begin{array}{l}\text { 1. Загальна оцінка діяльності } \\
\text { підприєства, його фрінансового стану. } \\
\text { 2. Виявлення «слабких місць» і } \\
\text { напрямів подальшого поглибленого } \\
\text { оцінювання. } \\
\text { 3. Визначення тенденції зміни } \\
\text { показників. } \\
\text { 4. Узагальнення результатів оцінки } \\
\text { фрінансового стану та стійкості } \\
\text { підприємства. } \\
\end{array}$ & $\begin{array}{l}\text { 1. Детальна характеристика } \\
\text { майнового і фрінансового стану } \\
\text { підприємства, результатів його } \\
\text { діяльності у минулому і звітному } \\
\text { періодах. } \\
\text { 2. Виявлення конкретних причин } \\
\text { порушення; } \\
\text { 3. Розробка рекомендації, щодо } \\
\text { покращення. }\end{array}$ \\
\hline $\begin{array}{c}\text { Прийоми, що } \\
\text { використовуються } \\
\text { при діагностиці }\end{array}$ & $\begin{array}{l}\text { Вертикальний дозволяє зробити } \\
\text { висновок про структуру балансу } \\
\text { в поточному стані, а також } \\
\text { проаналізувати динаміку цієї } \\
\text { структури. } \\
\text { Горизонтальний аналіз означає } \\
\text { метод співставлення значень } \\
\text { однакових показників протягом } \\
\text { певного часового періоду. }\end{array}$ & $\begin{array}{l}\text { Поглиблений аналіз фрінансового } \\
\text { стану передбачає розрахунок } \\
\text { аналітичних коефіцієнтів, що } \\
\text { дозволить оцінити різні сторони } \\
\text { діяльності підприємства: } \\
\text { майновий стан, ліквідність і } \\
\text { платоспроможність, фрінансову } \\
\text { стійкість, ділову активність, } \\
\text { рентабельність та ін. }\end{array}$ \\
\hline Подальші цілі & $\begin{array}{l}\text { Дозволяє з'ясувати основні } \\
\text { тенденції фрінансово-господарської } \\
\text { діяльності та на їх основі, визначити } \\
\text { пріоритетні напрями подальшого } \\
\text { поглибленого оцінювання. }\end{array}$ & $\begin{array}{l}\text { Конкретизує і доповнює окремі } \\
\text { процедури експрес-аналіз. }\end{array}$ \\
\hline
\end{tabular}


ситуацій, здійсненні попередніх заходів для їхнього забезпечення;

- впровадження планів практичних заходів при виникненні кризової ситуації, прийняття ризикових і нестандартних рішень у випадку відхилення розвитку ситуації;

- координацію дій всіх учасників і контроль за виконанням заходів та їхніми результатами.

Багато українських підприємств наразі переживають кризовий стан та мають досить незадовільне срінансове становище, тому багато вчених присвятили свої час для фрормування певних шляхів, які можуть поліпшити ситуацію та підвищити загальний фрінансовий стан підприємств.

План дій щодо поліпшення фрінансового стану підприємства повинен ґрунтуватися на даних діагностики, за допомогою якої були виявлені недоліки і на які необхідно звернути увагу в першу чергу. Так, як проведення аналізу включає у себе дослідження окремих показників, які характеризують певні сторони діяльності та стану фрункціонування підприємства, необхідно фрормувати план дій відповідно до покращення саме вихідних даних.

Початковим етапом у поліпшенні фрінансового стану підприємств $€$ знаходження оптимального відношення власного і позикового капіталу, що мало забезпечити мінімізацію фрінансового ризику за максимальної рентабельності власного капіталу. Оптимізація ліквідності підприємства здійснюється за рахунок механізму фрінансової стабілізації системи заходів, спрямованих, з одного боку, на зменшення фрінансових зобов'язань, а 3 іншого, мінімізації запасів незавершеного виробництва, та збільшення грошових активів, що забезпечують ці зобов'язання. Для підприємства першочерговим етапом стабілізації фрінансового стану $є$ досягнення такого рівня фрінансової стійкості, як досягнення повного самофрінансування виробничо-господарської діяльності у режимі простого відтворення. Тобто, необхідно досягти такого рівня стабілізації при якому забезпечується стійкість, як противага зниження об'ємів виробництва і руйнування ресурсного потенціалу. Більш досконалим етапом стабілізації фрінансового стану $є$ забезпечення такої фрінансової стійкості, яка зумовлює поступовий економічний ріст і перехід до розширеного відтворення. Важливим моментом $\epsilon$ забезпечення стійкості фрінансового стану підприємства, що зазвичай залежить від обсягу отриманого прибутку, що має забез- печувати зміцнення матеріально-технічної бази та приріст фрінансової ресурсів.

Немало важливим $є$ оптимізація оборотних коштів. Це ще один спосіб поліпшити фрінансовий стан компанії за рахунок прискорення обороту коштів компанії та зменшення виробничих витрат або надання послуг без втрати якості.

Окрім фрінансових методів, що застосовуються для поліпшення фрінансового стану компанії, застосовуються також економічні методи, що мають опосередкований вплив на срінансовий стан компанії. Одним 3 найважливіших способів $€$ оптимізації економічних та загальних бізнес- процесів $€$ поліпшення якості товару чи послуги, які компанія пропонує споживачам та збільшення доходу від реалізації продукції.

Висновки. Сучасні підприємства намагаються зробити свою діяльність більш ефективною, однією з передумов $є$ забезпечення економічної безпеки, здатність протистояти як зовнішнім так і внутрішнім загрозам. Але для того, щоб мати можливість до протидії загрозам необхідно мати уявлення про свої переваги та приховані резерви, а також вразливі місця.

Фінансовий стан $є$ головним показником, який показує те, як підприємство фуункціонує, бо містить всю інфрормацію про господарську діяльність того, чи іншого об'єкту. Аналіз та оцінка фрінансового стану підприємства допомагає сорормувати комплекс заходів, що допоможуть покращити орінансове становище підприємства та підвищити ефективність його роботи. Для цього використовується обліковоаналітична інсрормація, якій відводиться центральне місце у складі інорормаційного забезпечення. 3 одного боку, обліково-аналітичне забезпечення $€$ інфрормаційною основою для моніторингу стану та рівня економічної безпеки підприємства, а з іншого - специсічним видом профресійної діяльності в галузі безпеки, який безпосередньо впливає на її забезпечення. В процесі здійснення діагностики підприємства використовують різноманітні методи, прийоми та моделі, застосування яких визначається конкретним випадком та залежить від того на що саме направлено діагностику. Такий спосіб оцінки в результаті дасть змогу оцінити не лише підсумкові данні про рівень роботи підприємства, а й дозволить сорормувати напрямки, що допоможуть підвищити ефрективність діяльності підприємства, що відповідно призведе до покращення його фрінансового стану. 


\section{СПИСОК ВИКОРИСТАНИХ ДЖЕРЕЛ:}

1. Бенько М. М. Обліково-аналітичне забезпечення економічної безпеки підприємства : підручник. Київ, 2021. $560 \mathrm{c}$.

2. Гнилицька Л. В. Обліково-аналітичне забезпечення фрункціонування системи економічної безпеки суб'єктів господарювання як об'єкт наукових досліджень. Управління проектами та розвиток виробництва. 2011. № 1. С. 146-154.

3. Городня Т. А., Мойсеєнко І. П. Економічна та фрінансова діагностика : навч. посіб. Львів : Магнолія, 2014. 282 с.

4. Грінка Т. І. Сучасні проблеми обліково-аналітичного забезпечення в системі економічної безпеки підприємства. Наукові праці Кіровоградського національного технічного університету. Серія «Економічні науки». 2013. Вип. 23. С. 414-418.

5. Шепелюк В. А. Десрініції поняття «інфрормація» для обліково-аналітичного забезпечення в управлінні економічною безпекою підприємства. Вісник Донецького національного університету економіки і торгівлі ім. Михайла Туган-Барановського. Серія : «Економічні науки». 2017. Вип. 1. С. 185-191.

\section{REFERENCES:}

1. Benko M. M. (2021) Oblikovo-analitychne zabezpechennia ekonomichnoi bezpeky pidpryiemstva: pidruchnyk [Accounting and analytical support of economic security of the enterprise]. Kyiv: Lira-K. (in Ukrainian)

2. Hnylytska L. V. (2011) Oblikovo-analitychne zabezpechennia funktsionuvannia systemy ekonomichnoi bezpeky sub'iektiv hospodariuvannia yak ob'iekt naukovykh doslidzhen [Accounting and analytical support for the functioning of the economic security system of economic entities as an object of scientific research]. Project management and production development, no. 1, pp. 146-154.

3. Horodnia T.A., Moiseienko I.P. (2014) Ekonomichna ta finansova diahnostyka: navch. posib. [Economic and financial diagnostics]. Lviv: «Mahnoliya». (in Ukrainian)

4. Hrinka, T. I. (2013) Suchasni problemy oblikovo-analitychnoho zabezpechennia v systemi ekonomichnoi bezpeky pidpryiemstva [Modern problems of accounting and analytical support in the system of economic security of the enterprise]. Scientific works of Kirovograd National Technical University. Economic Sciences, vol. 23, pp. 414-418.

5. Shepeliuk V. A. (2017) Definitsii poniattia «informatsiia» dlia oblikovo-analitychnoho zabezpechennia v upravlinni ekonomichnoiu bezpekoiu pidpryiemstva [Definition of the concept of «information» for accounting and analytical support in the management of economic security of the enterprise]. Visnyk of Donetsk National University of Economics and Trade. Mikhail Tugan-Baranovsky. «Economic Sciences», vol. 1, pp. 185-191. 